\title{
Una complicación inusual del colgajo de Björk en la traqueotomía electiva
}

\author{
An unusual complication of Björk flap in elective tracheotomy
}

\author{
L. Villalaín Álvarez', J.C. de Vicente Rodríguez², I. Peña González', S. Llorente Pendás ${ }^{1}$
}

Resumen: Introducción. La traqueotomía temporal electiva se emplea con frecuencia en intervenciones realizadas en el territorio cervicofacial. El colgajo de pared traqueal anterior de base inferior (colgajo de Björk) facilita el cambio de cánula en el periodo postoperatorio. Caso clínico. Paciente intervenido de un cáncer oral al que tras haberse cerrado el traqueostoma se le descubrió de forma casual un hilo de sutura en la luz traqueal. Dada la dificultad de su retirada por vía endoscópica y ausencia de sintomatología, se decidió no retirarlo. Discusión. La traqueotomía electiva en oncología cervicofacial asegura la vía aérea, pero presenta también complicaciones. Es muy importante un adecuado manejo del traqueostoma, independientemente de que se elija un cierre primario o secundario del mismo.

Palabras clave: Traqueotomía; Colgajo de pared traqueal; Colgajo de Björk; Endoscopia traqueal.

Recibido: 12.05.2008

Aceptado: 15.10 .2008
Abstract: Introduction. Elective temporary tracheotomy in often performed in head and neck oncologic surgery. An inferiorly hinged tracheal flap (Björk flap) provides a secure airway in the inmediate postoperative period. Clinical case. This patient underwent resection of an oral cancer and subsequent tracheotomy. After deccanulation, a piece of suture was found into the trachea as an incidental discovery. There were no symptoms related to it, and it was not possible to remove it from the anterior tracheal wall by means of endoscopy, so it was left in place. Discussion. Elective tracheotomy in head and neck resection for malignancy safeguards the airway, but also has complications. It is very important a careful management of the stoma, without regard if a primary or secundary closure of it is chosen.

Key words: Tracheotomy; Tracheal wall flap; Björk flap; Tracheal endoscopy.

\footnotetext{
1 Médico Adjunto

2 Jefe de Sección

Servicio de Cirugía Oral y Maxilofacial.

Hospital Universitario Central de Asturias. Oviedo, España
}

Correspondencia:

Lucas Villalaín Alvarez

C. Piloña ${ }^{\circ} 236^{\circ} \mathrm{H}$

33006 Oviedo. España

Email: Ivillalain@hotmail.com 


\section{Introducción}

El término traqueotomía deriva de los términos griegos tracheia arteria, conducto áspero o ronco y tomos, sección, y se emplea para definir la intervención consistente en practicar una apertura en la luz de la tráquea. El término traqueostomía deriva de tracheia arteria y de otro término griego, stoma, boca, y significa abocar la luz de la tráquea a la piel de la parte anterior del cuello. Pese a estas diferencias etimológicas, en general ambos términos se emplean indistintamente en la literatura médica.

La traqueotomía es una técnica conocida desde la Edad Antigua. Sin embargo, debido a la elevada tasa de fracasos y complicaciones que presentaba, no es hasta finales del siglo XIX cuando se introduce en la práctica médica. A principios del siglo XX Chevalier Jackson realiza el primer esfuerzo importante por estandarizar sus indicaciones, instrumental y técnica.1,2

La traqueotomía electiva en intervenciones oncológicas en el territorio craneomaxilofacial se realiza de forma profiláctica cuando se prevé que en el periodo postoperatorio se puedan producir situaciones que comprometan la vía aérea del paciente, tales como edemas o hematomas. Sería, de esta forma, la alternativa a una intubación endotraqueal prolongada para asegurar la permeabilidad de la vía aérea. ${ }^{3-6}$

De los diferentes pasos que constituyen la técnica quirúrgica, el que ofrece una mayor variabilidad, en función de la preferencia de los diferentes autores, es el modo de apertura de la pared traqueal anterior. ${ }^{1}$ Así, se proponen incisiones horizontales, ${ }^{7}$ resecciones de un segmento rectangular o circular de pared traqueal, 2,8 y creaciones de colgajos de pared anterior traqueal de base superior ${ }^{9} \mathrm{O}$ inferior. ${ }^{10-12}$ Este último tipo fue usado por Björk por vez primera en 1960.3

Como cualquier otro procedimiento quirúrgico, la traqueotomía no está exenta de complicaciones, algunas de ellas muy graves. $1,2,11$

\section{Caso clínico}

Paciente varón de 64 años de edad que acudió al Servicio de Cirugía Oral y Maxilofacial del Hospital Universitario Central de Asturias por presentar un carcinoma de células escamosas que afectaba al borde lingual, la pared lateral orofaríngea, el área amigdalar y el hemipaladar blando izquierdos. Presentaba asimismo grandes adenopatías metastásicas en los ejes vasculares y en las regiones submaxilares de ambos lados del cuello.

En un primer tiempo quirúrgico se realizó la resección del tumor, un vaciamiento cervical radical clásico izquierdo y una reconstrucción del defecto con un colgajo microvascularizado fasciocutáneo anterolateral de muslo. Tres semanas más tarde se procedió a realizar un vaciamiento cervical radical clásico derecho. Dada la magnitud de la cirugía y en previsión de posibles complicaciones postoperatorias, en la primera intervención se practicó también una traqueotomía reglada electiva, empleando el colgajo de Björk como modo de apertura de la tráquea. La traqueotomía se mantuvo hasta varios días después de la segunda intervención, produciéndose

\section{Introduction}

The term "tracheotomy" derives from the Greek terms tracheia arteria, rough or coarse tube, and tomos, section, and it is used to define the operation of cutting an opening into the tracheal lumen. The term "tracheostomy" derives from tracheia arteria and another Greek term, stoma, mouth, and refers to an opening in the tracheal lumen and skin of the anterior neck. Despite these etymologic differences, the two terms generally are used interchangeably in medical literature.

Tracheotomy is a technique known from Classical Antiquity. However, due to the high rate of failures and complications that accompany it, tracheotomy did not enter routine medical practice until the end of the nineteenth century. At the beginning of the twentieth century, Chevalier Jackson made the first concerted effort to standardize tracheotomy indications, instruments, and technique. ${ }^{1,2}$

Elective tracheotomy in oncologic interventions on the craniomaxillofacial territory is performed prophylactically when it is expected that situations may arise in the postoperative period that can compromise the patient's airways, such as edema or hematoma. It is an alternative to prolonged endotracheal intubation to ensure airway patency. . $^{3-6}$

Of the different steps involved in the tracheotomy technique, the one that varies most is how the anterior tracheal wall is opened, which depends on different authors' preference. 1 Proposals include horizontal incisions, 7 resections of a rectangular or circular segment of tracheal wall, $, 2,8$ and creation of tracheal anterior wall flaps based superiorly or inferiorly..$^{10-12}$ The latter type was used by Björk for the first time in 1960.3

Like any other surgical procedure, tracheotomy is not free of complications and some of them are serious.1,2,11

\section{Clinical case}

A 64-year-old male patient was seen in the Oral and Maxillofacial Surgery Department of the Central University Hospital of Asturias for a squamous-cell carcinoma of the lingual edge, oropharyngeal lateral wall, tonsil area, and soft palate on the left side. The patient also had marked metastatic lymph node enlargement along the vascular axes and submaxillary regions on both sides of the neck.

In the first operation, the tumor was resected, left classic radical lymph node dissection was performed, and the defect was reconstructed with an anterolateral microvascularized fasciocutaneous flap from the thigh. Three weeks later, classic right radical lymph node dissection was performed. Given the magnitude of the surgery and the likelihood of postoperative complications, an elective regulated tracheotomy also was practiced in the first operation and a Björk flap was created to cover the tracheal opening. The tracheotomy was maintained until several days after the sec- 
un cierre espontáneo del traqueostoma tras decanular al paciente y liberar la unión del colgajo traqueal a la piel (Fig. 1).

Posteriormente el paciente recibió tratamiento radioterápico complementario sobre la cavidad oral, la orofarínge y los niveles ganglionares cervicales I al VI.

En una TC cervicotorácica de control, solicitado 4 meses tras la cirugía, se apreció la existencia de una pequeña masa compatible con proceso neoplásico en el lóbulo medio pulmonar derecho, motivo por el que fue remitido al Servicio de Neumología. Se realizó entonces una broncoscopia, en la cual se observó un hilo de sutura en la luz de la tráquea, de color negro, de unos 2,5 $\mathrm{cm}$ de longitud, insertado por uno de sus extremos en la pared traqueal anterior (Fig. 2). Se intentó retirar, pero al comprobar que estaba fijado firmemente, y para evitar posibles desgarros en la pared de la tráquea, se optó por no hacerlo. Finalmente, la masa pulmonar resultó ser de naturaleza inflamatoria y se resolvió espontáneamente.

En relación con el hilo de sutura traqueal, la única sintomatología referida por el paciente era, ocasionalmente, sensación de cuerpo extraño, sin llegar a producir tos ni disnea.

\section{Discusión}

Dentro de las indicaciones de la traqueotomía, se incluyen aquellos casos de cirugía en los que se prevean posibles complicaciones en el postoperatorio que supongan un compromiso de la vía aérea. ${ }^{1,2}$ El tipo de cirugía al que nos referimos es fundamentalmente la cirugía oncológica que implique un procedimiento ablativo de un tumor locali-

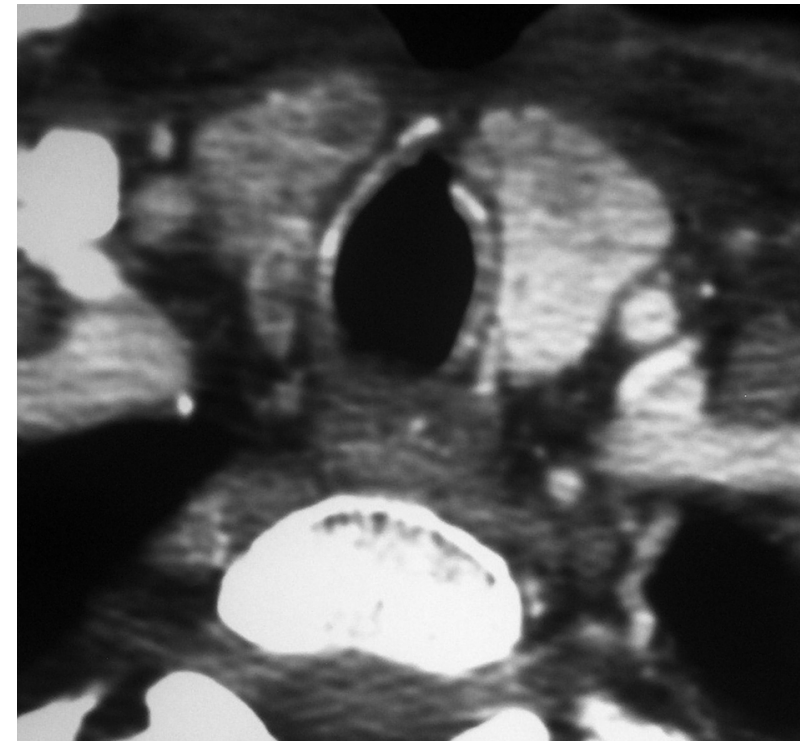

Figura 1. Imagen obtenida mediante tomografía computerizada del lugar donde se realizó la traqueotomía. Se aprecian una adecuada cicatrización de los tejidos blandos pretraqueales y la ausencia de estenosis de la luz de la tráquea.

Figure 1. Computed tomography image of the tracheotomy site. Adequate healing of the pretracheal soft tissues and absence of stenosis of the tracheal lumen.

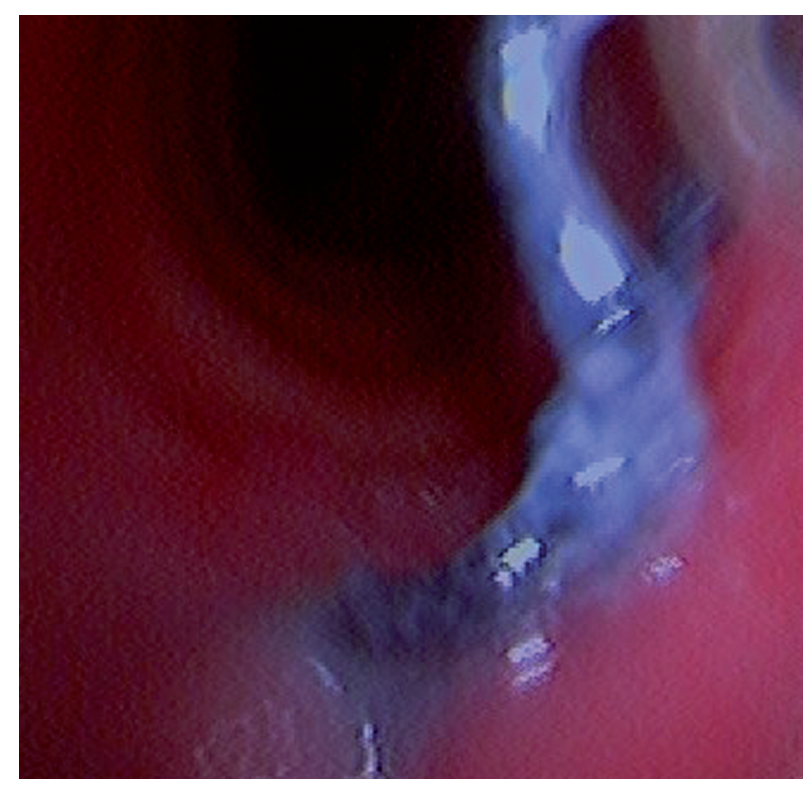

Figura 2. Imagen obtenida con el broncoscopio dentro de la tráquea: Se aprecia como el hilo de sutura se inserta en la pared traqueal anterior.

Figure 2. Image obtained with a bronchoscope inserted in the trachea: a suture is visible on the tracheal anterior wall. ond intervention. The tracheostoma closed spontaneously after decannulating the patient and releasing the tracheal flap attachment to the skin (Fig. 1). The patient later received complementary irradiation of the oral cavity, oropharynx, and cervical lymph nodes at levels I to VI. In control CT scanning of the cervicothoracic area ordered 4 months after surgery, a small mass consistent with a neoplastic process was observed in the right middle lung lobe and the patient was referred to the Pneumology Department. Bronchoscopy detected a black suture in the tracheal lumen, about 2.5 $\mathrm{cm}$ long, with one end attached to the tracheal anterior wall (Fig. 2). Removal was attempted, but it was firmly affixed and the decision was made to leave it to avoid potential tearing of the tracheal wall. The pulmonary mass was found eventually to be inflammatory and it resolved spontaneously.

The only symptoms of the tracheal suture referred by the patient were an occasional sensation of foreign body, without producing coughing or dyspnea.

\section{Discussion}

The indications for tracheotomy include cases of surgery in which possible postoperative complications are foreseeable that may compromise airways. ${ }^{1,2}$ Such interventions are fundamentally oncologic surgery involving ablation of a tumor located in the upper airway or digestive tract, generally associated with cervical lymph node dissection. The complications that may affect airways are mainzado en la vía aerodigestiva superior y, generalmente, algún tipo de disección cervical asociada. Las posibles complicaciones que comprometan la vía aérea son sobre todo el edema tisular y la aparición de hematomas. ${ }^{3,4}$ La alternativa a la traqueotomía en estos casos es el mantenimiento postoperatorio de la intubación endo- ly tissue edema and the development of hematoma. ${ }^{3,4}$ The alternative to tracheotomy in these cases is postoperative maintenance of endotracheal intubation. Neither tracheotomy nor prolonged intubation is free of complications. The rate of complications, some of them mortal, associated with tra- 
traqueal. Ni la traqueotomía ni la intubación prolongada están exentas de complicaciones La tasa de complicaciones, algunas de ellas mortales, asociadas a la traqueotomía aumentan cuando ésta se hace con carácter de urgencia, situación que puede ocurrir en el periodo postoperatorio de cirugías oncológicas cervicofaciales, como señalamos anteriormente. En este sentido, los esfuerzos deben dirigirse a conseguir determinar preoperatoriamente, atendiendo a las características del tumor y del paciente, las posibilidades de aparición de compromiso respiratorio tras la cirugía, para poder seleccionar adecuadamente a los pacientes a los que se les va a realizar una traqueotomía electiva. 5,6 En el paciente aquí presentado decidimos practicarla por varios motivos. Por un lado, se trataba de un tumor muy extenso, localizado en una zona de gran compromiso de la vía aérea superior, cuyo defecto se iba a reconstruir utilizando un colgajo microvascularizado, por lo que era de esperar un importante edema postoperatorio de los tejidos blandos orales y orofaríngeos. Por otro lado se iba a realizar una disección cervical radical clásica, procedimiento con riesgo de desarrollar un hematoma cervical. Por último estaba previsto realizar un segundo vaciamiento cervical tres semanas después de la primera cirugía, lo que requeriría una nueva intubación, difícil de llevar a cabo a través de una orofarínge recientemente intervenida.

El tipo de apertura traqueal elegida fue la incisión horizontal entre el $2^{\circ}$ y el $3^{\text {er }}$ anillos traqueales y posterior creación de un colgajo de pared traqueal anterior de base inferior (colgajo de Björk, trampilla o charnela inferior) suturado directamente a la piel. Elegimos este colgajo porque creemos, de acuerdo a la opinión de otros autores, que facilita los cambios de cánula en el periodo postoperatorio, disminuyendo el riesgo de creación de una falsa vía o de imposibilidad de reintroducción de la cánula. Por otro lado, parece demostrado que este tipo de incisión, en comparación con otras, condiciona un menor grado de estenosis traqueal. $1,3,4,10,11$

No existe un criterio unánime acerca de cómo se debe realizar el cierre del traqueostoma una vez decanulado el paciente. Para acelerar el proceso y evitar las posibles consecuencias de una cicatrización defectuosa por segunda intención (estenosis traqueal, retracción cutánea, disminución de movilidad traqueal, establecimiento de fístulas traqueocutáneas y cicatrices inestéticas), algunos autores recomiendan el cierre quirúrgico de la traqueotomía, realizando una reposición anatómica del colgajo cartilaginoso traqueal y una sutura por planos, ${ }^{1}$ o al menos una liberación del colgajo traqueal de los tejidos blandos vecinos. ${ }^{13}$ Sin embargo, el cierre primario acarrea una serie de riesgos, como el de aparición de enfisema subcutáneo, neumomediastino o neumotórax. ${ }^{14}$ La mayoría de los autores recomiendan esperar al cierre de forma espontánea, por segunda intención, reservando el cierre quirúrgico de los traqueostomas para aquellos casos de largo tiempo de evolución, en los que se haya establecido una fístula traqueocutánea. 2,3,11,12

Nosotros mostramos el caso de un paciente al que se le encontró de forma accidental, en el curso de una broncoscopia realizada por otro motivo, una sutura en la luz traqueal. Dicha sutura, medía $2,5 \mathrm{~cm}$ aproximadamente y se insertaba por uno de sus extremos en la pared traqueal anterior. Casi con total seguridad, se trata de una de las suturas de seda que en su momento fijó el colgajo traqueal a la piel. No podemos demostrar exactamente por qué se cheotomy increase when the procedure is performed under emergency conditions, a situation that may arise in the postoperative period of cervicofacial oncologic surgery, as mentioned above. In this sense, efforts must focus on determining before surgery, on the basis of the characteristics of the tumor and patient, what possibility exists that respiratory compromise could occur after surgery, in order to properly select the patients who will undergo elective tracheotomy. 5,6 Tracheotomy was performed in the case reported here for several reasons. On the one hand, the tumor was extensive, located in an area in which there was a risk of upper airway compromise, and the proposed defect reconstruction was with a microvascularized flap. Consequently, considerable postoperative edema of the oral and oropharyngeal soft tissues was expected. On the other hand, classic radical cervical lymph node dissection was planned, which is associated with a risk of cervical hematoma. Finally, a second cervical dissection was scheduled 3 weeks after the first operation, which would require a new intubation that would be difficult to perform on a recently intervened oropharynx.

The type of tracheal opening chosen was a horizontal incision between the second and third tracheal rings, followed by creation of a tracheal anterior wall flap with an inferior base (Björk flap, hatch, or lower hinge) sutured directly to the skin. We chose this flap because we believe, as other authors do, that it facilitates the change of cannula in the postoperative period, diminishing the risk of creating a false pathway or impeding cannula reintroduction. On the other hand, it seems to be clear that this type of incision, compared with others, produces less tracheal stenosis. $1,3,4,10,11$

No consensus exists as to how a tracheostoma should be closed when the patient is decannulated. In order to accelerate the process and avoid the possible consequences of defective healing by second intention (tracheal stenosis, skin retraction, diminished tracheal mobility, establishment of tracheocutaneous fistulas, and disfiguring scars), some authors recommend surgical closure of the tracheotomy by anatomically repositioning the tracheal cartilaginous flap and suturing by planes' or, at least, releasing the tracheal flap from neighboring soft tissues. ${ }^{13}$ However, primary closure entails risks, such as the appearance of subcutaneous emphysema, pneumomediastinum, or pneumothorax. ${ }^{14}$ Most authors recommend waiting for spontaneous closure by second intention, reserving surgical closure of tracheostomas for cases of long duration in which a tracheocutaneous fistula has formed. 2,3,11,12

The case reported here involved a patient in which a suture in the tracheal lumen was encountered incidentally in the course of bronchoscopy for another purpose. This suture measured approximately $2.5 \mathrm{~cm}$ and was attached at one end to the anterior tracheal wall. It is practically certain that it was one of the silk sutures that had affixed the tracheal flap to the skin. We could not explain exactly why it was found in that position. It is likely that when the stitches that 
encuentra en esa posición. Probablemente, al realizar la retirada de los puntos que fijaban el colgajo traqueal a la piel, uno de ellos quedó de forma inadvertida unido al colgajo traqueal liberado. Este colgajo se reposicionó dorsalmente de forma espontánea, arrastrando consigo la sutura no retirada, con el nudo de la misma situado sobre su cara externa (Figs. 3A y 3B). Esto explicaría la dificultad para extraer la sutura desde la luz traqueal mediante broncoscopio.

Existe un caso similar al nuestro descrito en la literatura, ${ }^{15}$ al que se le retiró la sutura mediante microcirugía laríngea. En este caso la sutura se introducía entre las cuerdas vocales, el paciente percibía sensación de cuerpo extraño y sufría tos intermitente.

Nosotros, de acuerdo con nuestro paciente, decidimos no proceder a extraer la sutura, dado que era de
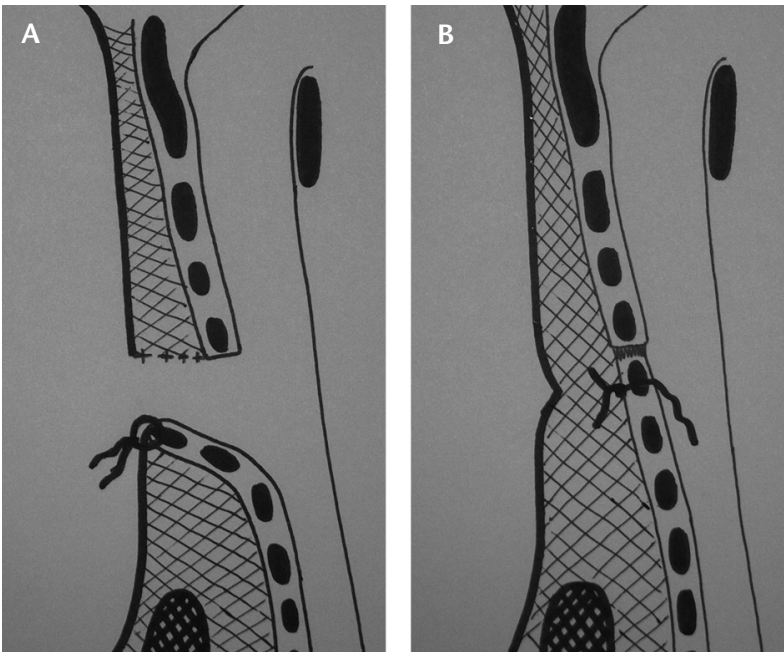

Figura 3. Dibujos esquemáticos de un corte sagital medio del cuello. A) Se aprecia el colgajo traqueal unido mediante un punto de sutura a la piel cervical. B) Se muestra la cicatrización de colgajo de Björk en la pared traqueal anterior, con el hilo de sutura en el interior de la luz traqueal y el nudo sobre la cara externa del colgajo reposicionado.

Figure 3. Diagram of a medial sagittal slice of the neck. A) Tracheal flap attached by a stitch to the cervical skin. B) The Björk flap in the tracheal anterior wall is healed and there is a suture inside the tracheal lumen with a knot on the external face of the repositioned flap. localización subglótica, la única sintomatología que causaba, de forma ocasional, era sensación de cuerpo extraño y el paciente no deseaba someterse a más procedimientos quirúrgicos.

\section{Conclusiones}

El colgajo de pared traqueal anterior de base inferior (colgajo de Björk, trampilla o charnela inferior) asegura y facilita el cambio de cánula en el periodo postoperatorio de pacientes a los que se les ha practicado una traqueotomía temporal electiva.

Es muy importante un adecuado manejo postoperatorio del traqueostoma, independientemente de que se elija un cierre primario o secundario del mismo.

\section{Bibliografía}

1. Suárez C. Tratado de Otorrinolaringología y Cirugía de Cabeza y Cuello. Tomo III. Madrid, Editorial Proyectos Médicos, S.L., 1999;2065-74.

2. Paparella M, Shumrick D. Otolaryngology. Volume 3. Philadelphia, W.B. Saunders Company, 1973;845-56.

3. Malata CM, Foo IT, Simpson KH, Batchelor AG. An audit of Bjork flap tracheostomies in head and neck plastic surgery. Br J Oral Maxillofac Surg 1996;34: 426.

4. Demas PN, Sotereanos GC. The use of tracheotomy in oral and maxillofacial surgery. J Oral Maxillofac Surg 1988;46:483-6.

5. Crosher R, Baldie C, Mitchell R. Selective use of tracheostomy in surgery for head and neck cancer: an audit. Br J Oral Maxillofac Surg 1997;35:43-5. affixed the tracheal flap to the skin were removed, a stitch remained inadvertently attached to the tracheal flap when it was released. This flap spontaneously acquired a dorsal position, dragging along with it the suture that had not been removed and the suture knot situated on its external face (Figs. $3 A$ and $3 B$ ). This would explain why the suture could not be removed from the tracheal lumen by bronchoscopy.

A similar case has been reported in the literature, ${ }^{15}$ in which the suture was removed by laryngeal microsurgery. In this case, the suture was introduced between the vocal cords and the patient perceived a foreign body sensation and suffered intermittent coughing.

In a decision reached with our patient, we decided not to remove the suture because it was subglottal and only originated occasional symptoms of foreign body sensation. Moreover, the patient did not wish to undergo more surgical interventions.

\section{Conclusions}

The inferiorly based, tracheal anterior wall flap (Björk flap, hatch, or inferior hinge) ensures and facilitates the change of cannula in the postoperative period of patients who undergo an elective temporary tracheotomy.

Proper postoperative management of the tracheostoma is very important, regardless of whether primary or secondary closure is chosen. 
6. Kruse-Losler B, Langer E, Reich A, Joos U, Kleinheinz J. Score system for elective tracheotomy in major head and neck tumour surgery. Acta Anaesthesiol Scand 2005;49:654-9.

7. Lin ZM, Chen PR, Chou AS, Hsu LP. Tracheal incision for elective tracheotomy in oral cavity cancer. Oral Oncol 2007;43:15-9.

8. Kremer B, Botos-Kremer Al, Eckel HE, Schlondorff G. Indications, complications, and surgical techniques for pediatric tracheostomies-an update. J Pediatric Surg 2002;37:1556-62.

9. Rhee CK, Miller FR, Tucker HM, Eliachar I. The superiorly based flap long-term tracheostomy in pediatric patients. Am J Otolaryngol 1996; 17:251-6.

10. Lulenski GC. Long-term tracheal dimensions after flap tracheostomy. Arch Otolaryngol 1981;107:114-6.
11. Goldenberg D, Ari EG, Golz A, Danino J, Netzer A, Joachims HZ. Tracheotomy complications: a retrospective study of 1130 cases. Otolaryngol Head Neck Surg 2000;123:495-500.

12. Anil K. Lalwani. Diagnóstico y tratamiento en otorrinolaringología, cirugía de cabeza y cuello. México, Editorial El Manual Moderno, 2005; 520-4.

13. Lulenski GC, Batsakis JG. Management of the flap tracheostomy. An experimental study. Arch Otolaryngol 1979;105:260-3.

14. Stanton DC, Kademani D, Patel C, Foote JW. Management of posttracheotomy scars and persistent tracheocutaneous fistulas with dermal interpositional fat graft. J Oral Maxillofac Surg 2004;62:514-7.

15. Spiegel JR, Sataloff RT, Hoover CA. Laryngeal foreign body in a former tracheotomy patient. Ear Nose Throat / 1997;76:490. 